\title{
Injecties in bil bij knieartrose
}

Bij het artikel 'Onderzoek naar injecties in de bil bij knieartrose' van Marianne Mol [Huisarts Wet 2018;61[9]:67] verschenen op de website enkele reacties. Daar staan ook de bijbehorende referenties.

\section{NADELEN OP LANGERE TERMIJN}

In het artikel 'Onderzoek naar injecties in de bil bij knieartrose' staat: 'Bij patiënten met heupartrose bleken intramusculaire injecties een significante, klinisch relevante en langdurige vermindering van pijnklachten te geven'. De auteur vergeet de zin af te maken met 'ten opzichte van placebo IM-injectie'. Er wordt in besproken artikel geen vergelijking van effect gemaakt ten opzichte van intra-articulaire injecties.

Overigens is mijn terughoudendheid niet zozeer vanwege gebrekkige routine, maar vanwege de nadelen op langere termijn. ${ }^{1}$ Een non-inferioriteitsonderzoek op langere termijn van 'herhaalde intramusculair versus intra-articulaire corticosteroïdtoediening' zou ik erg interessant vinden.

Christian van Rij

\section{VERSCHIL MET PREDNISON}

In de discussie over de werkzaamheid van intramusculaire injecties bij knieartrose vraag ik me af hoeveel verschil er is met dagelijks een lage dosis prednison slikken. Als algemene ontsteking een rol speelt, zoals bij steeds meer chronische aandoeningen blijkt, en ook (weer) centrale sensitisatie, zou het sluiten van een patent foramen ovale nuttig kunnen zijn. ${ }^{1}$ Hier wordt met massaspectrometrie eenduidig aangetoond dat - het pro-inflammatoire - serotonine significant daalt na sluiting. Complicaties op langere termijn zijn waarschijnlijk ook kleiner dan bij langdurig corticosteroïdengebruik.

Wijnand van den Berg

\section{PREFERENTE INJECTIEPLAATS}

De foto bij het artikel over injecties in de bil bij knieartrose lijkt te suggereren dat preferente injectieplaats in de buurt van de N. ischiadicus is. Dat lijkt me niet de bedoeling?

Cornelie van der Burg

\section{Onderzoek naar injecties in de bil bij knieartrose}

Marianne Mol

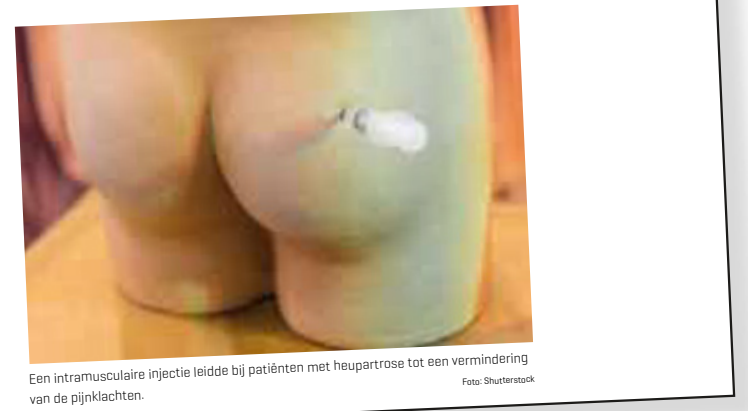

\section{REACTIE AUTEUR}

Het is geenszins mijn bedoeling geweest om te verdoezelen dat de geciteerde studie van Dorleijn et al. een placebogecontroleerd onderzoek is. ${ }^{1}$ De vergelijking tussen intramusculaire en intra-articulaire injectie bij heupartrose die u voorstelt is zeker interessant. Het uitvoeren van dat onderzoek is op onze afdeling overwogen, maar [nog] niet uitgevoerd aangezien intra-articulaire injectie in de heup een invasieve behandeling is.

Op het, overigens belangrijke, onderzoek van McAlindon et al. is het een en ander aan te merken. In een ingezonden brief in JAMA stond dat de corticosteroïdeninjecties in dit onderzoek gedurende twee jaar elke drie maanden werden toegediend. ${ }^{2}$ Dit ongeacht de mate van klachten en onafhankelijk van de aanwezigheid van een opvlamming van artrose. Dit strookt niet met de praktijk waarin corticosteroïdeninjectie onder andere een rol heeft bij een dergelijke opvlamming. Daarnaast is onzeker of het vastgestelde verlies van kraakbeenvolume op MRI voldoende is om klinische achteruitgang te veroorzaken. Aan de Knieartrose Injectie Studie mogen alleen patiënten meedoen die matige tot ernstige kniepijn hebben. Tijdens de follow-up periode van het onderzoek mag de huisarts nogmaals een corticosteroïdeninjectie toedienen indien daar een indicatie voor bestaat [opnieuw opvlamming van kniepijn]. Daarbij wordt de NHG-Standaard Niet-traumatische knieklachten gevolgd, waarin staat dat injecties maximaal vier keer per jaar mogen worden toegediend. Herhaaldelijk toedienen van injecties [los van de klachten van een patiënt] zoals in het onderzoek van McAlindon et al., lijkt mij niet zinvol.

Orale corticosteroïden zouden inderdaad werkzaam kunnen zijn bij artrose. Hier zijn tot nu toe enkele onderzoeken naar gedaan, maar de resultaten zijn niet eenduidig. ${ }^{1,2}$ Ook is daarnaast bekend dat van een injectie een groter placebo-effect uitgaat dan van een tablet. ${ }^{3}$ Inflammatie speelt een rol bij de pathogenese van artrose en inflammatie kan leiden tot centrale sensitisatie. ${ }^{4}$ Interessant is dat beschreven is dat centrale sensitisatie bij knieartrosepatiënten afneemt na een gewrichtsvervangende operatie. ${ }^{5}$

De afbeelding [die ik overigens niet heb gekozen] geeft inderdaad niet juist weer hoe de intramusculaire injecties in dit onderzoek worden toegediend. In plaats van de dorsogluteale toedieningsweg passen wij de ventrogluteale injectietechniek toe. In het ventrogluteale injectiegebied lopen geen belangrijke neuromusculaire structuren. ${ }^{1}$ Daarnaast is de subcutane vetlaag daar dunner, waardoor er een grotere kans is om werkelijk intramusculair te injecteren. ${ }^{2}$ Dit is relevant aangezien knieartrose vaker voorkomt bij patiënten met een hoog BMI $\left[>27 \mathrm{~kg} / \mathrm{m}^{2}\right]^{3}$

Marianne Mol, aioto en uitvoerend onderzoeker KIS-studie 